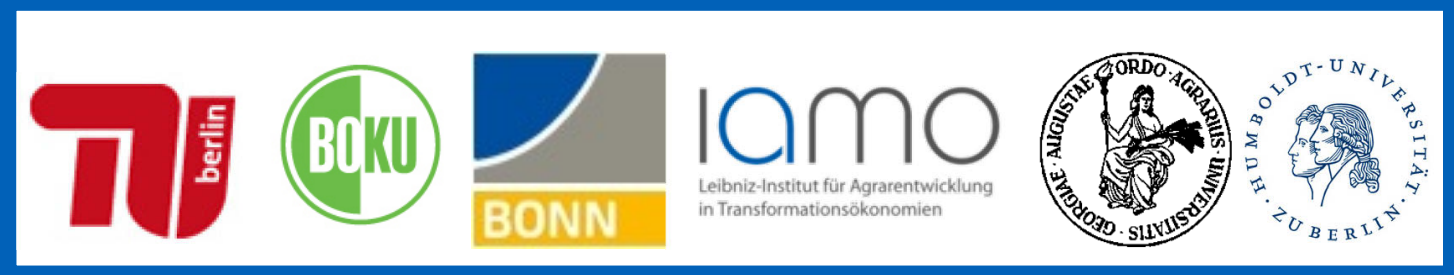

\title{
FORLAND
}

\section{Measuring Liquidity in Agricultural Land Markets}

Marlene Kionka, Martin Odening, Jana Plogmann, Matthias Ritter

\section{FORLand-Working Paper 25 (2020)}

\section{Published by}

DFG Research Unit 2569 FORLand, Humboldt-Universität zu Berlin Unter den Linden 6, D-10099 Berlin

https://www.forland.hu-berlin.de (C) $(1) \Theta$

Tel +49 (30) 2093 46845, Email gabriele.wuerth@agrar.hu-berlin.de

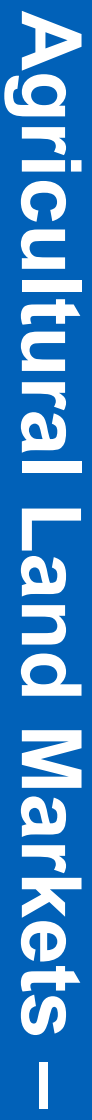




\title{
Measuring Liquidity in Agricultural Land Markets
}

\author{
Marlene Kionka *, Martin Odening ${ }^{* *}$, Jana Plogmann ${ }^{* * *}$, Matthias Ritter ${ }^{* * * *}$
}

December 2020

\begin{abstract}
This paper contributes to the sparse empirical literature on measuring liquidity in agricultural land markets. Using data from Lower Saxony (Germany), we inspect the spatial and temporal variability of various liquidity indicators. We apply a panel vector autoregression (VAR) and Granger causality tests to examine the relationship between liquidity and prices and to identify further determinants of land market liquidity, such as supply shocks and clientele effects. Unlike in housing markets, no positive relationship between prices and market liquidity exists. We conclude that in agricultural land markets, a high demand from expanding farms absorbs supply shocks regardless of prevailing prices.
\end{abstract}

Keywords: Agricultural land markets, liquidity indicators, panel vector autoregressive model, Granger causality

JEL codes: Q13, Q24, C32, C33

\section{Acknowledgements}

Financial support from the German Research Foundation (DFG) through Research Unit 2569 "Agricultural Land Markets - Efficiency and Regulation" (www.forland.hu-berlin.de) is gratefully acknowledged. The authors thank the Oberer Gutachterausschuss für Grundstückswerte for providing data on farmland sales in Lower Saxony.

* Marlene Kionka, marlene.kionka@agrar.hu-berlin.de

** Martin Odening, m.odening@agrar.hu-berlin.de

*** Jana Plogmann, jana.maria.plogmann@agrar.hu-berlin.de

**** Matthias Ritter, matthias.ritter@agrar.hu-berlin.de

All authors are at Humboldt-Universität zu Berlin, Faculty of Life Sciences, Department of Agricultural Economics, Unter den Linden 6, D-10099 Berlin. 


\section{Introduction}

Agricultural land markets are generally characterized as thin (Bigelow et al. 2020, Nickerson and Zhang 2014, Sherrick and Barry 2003). In 2019, $0.52 \%$ of agricultural land was sold in Germany (Destatis 2020). The share of agricultural land sold in other EU Member States, such as France, Ireland, and Sweden, was also below $1 \%$ annually between 2005 and 2015 (Loughrey et al. 2019). Likewise, in the U.S., it is estimated that just over $2 \%$ was sold in the open market for the period between 2014 and 2019 (Bigelow et al. 2016). Reasons for this market thinness that is found in the literature are immobility, heterogeneity, as well as high search and transaction costs of this asset class (Borchers et al. 2014, Graubner 2018, Hüttel et al. 2016, Lence 2001). Why is this an issue? Liquidity is usually considered as an important factor for the efficient functioning of a market. In financial markets, liquidity refers to the ability to trade an asset quickly, in large quantities, and with little impact on the price. A liquid market is characterized by continuity, i.e., immediate trading, and efficiency, i.e., any amount can be bought or sold at prices near the current market price (Black 1971). Poor liquidity bears the risk of either paying additional premia on top of a "fundamental" value or losing money if an immediate transaction will be enforced. In the most extreme case, the market freezes and no transactions take place. Thus, illiquidity affects the efficiency of the market since market participants are not able to realize their desired purchase or sell transactions without delay. Another important function of liquidity is the improvement of price discovery for the market. A liquid market attracts more informed traders and alters the informativeness of prices (Admati and Pfleiderer 1998).

Liquidity in financial markets has been examined well in the literature. The relationship between return and liquidity is investigated by Amihud (2002). The author identifies an illiquidity premium and finds a positive effect in the long-run of expected market illiquidity on expected stock excess returns. Thus, liquidity affects asset prices and returns (Amihud and Mendelson 2006). Hasbrouck and Seppi (2001) examine variation and common covariation in various liquidity proxies and market depth (trade impact) coefficients. Chordia et al. (2002) investigate the variation of aggregated market liquidity over time. They identify several factors that influence liquidity, such as equity market returns and market volatility. Adämmer et al. (2016) investigate the extent to which thinly traded agricultural futures markets fulfil their price discovery function. Using co-integration techniques, they find that a relatively low trading volume is sufficient for efficient price discovery. Thus, price signals in thin future markets are still reliable.

Studies on price formation in farmland markets often refer to thinness as a price determinant, but solely in a qualitative manner (cf. Nickerson and Zhang 2014: 121). For example, Hüttel et al. (2014) hypothesize that the presence of a price discount in farmland foreclosures is due to the immediacy of the transaction. Cotteleer et al. (2008) and Kuethe and Bigelow (2018) argue that Rosen's classical hedonic pricing framework requires fully competitive markets, whereas in thin markets, the buyers' willingness to pay and sellers' willingness to accept may overlap. This entails the opportunity for price negotiations, in which market power and bargaining power can be exercised. Yang et al. (2019) find that adjustments in regional land price differentials take place rather slowly and trace this to market thinness. 
Though the relevance of thinness in farmland markets is acknowledged, little quantitative empirical knowledge is available. Moreover, the relationship between market liquidity and prices in land markets is not well understood. It is not even apparent if this relationship is positive or negative. Furthermore, it is not clear which factors determine the likelihood of a land market transaction, such as a match between the willingness to pay of potential buyers and the willingness to accept of potential sellers in a specific market situation. The objective of this paper is to address this research gap. More specifically, we pursue the following research questions:

How can farmland market liquidity be measured and what indicators are most useful? How does market liquidity change over time and across regions? How can land market liquidity be modelled and what is its relationship with farmland values? We explore these questions for the agricultural land market in Lower Saxony, an agrarian state in northwestern Germany.

The remainder of this article is structured as follows: In the next section, we identify different liquidity indicators and review literature on determinants of market liquidity; Section 3 describes the relevant data and study region; Section 4 exhibits the spatial representation and temporal development of different liquidity indicators, as well as investigates the relationship between liquidity and farmland values by means of a VAR model and Granger causality tests; and Section 5 provides conclusions and an outlook for further research.

\section{Measuring and Modelling Market Liquidity}

\subsection{Dimensions and Indicators of Liquidity}

In general, market or asset liquidity describes the "ease" in which an asset can be traded (Hibbert et al. 2009). However, it is a complex notion that encompasses several dimensions. Kyle (1985) categorizes the measurement of liquidity into three dimensions: tightness, depth, and resiliency. Tightness refers to the cost of turning over a position in a short period of time. These costs include direct trading costs (exchange or auction fees, brokerage commissions, and transactions taxes), as well as the price impact of the trade relative to the "fair" or "fundamental" value of the asset, which arises from the imperfectly elastic demand and supply for the asset. Depth means the size of buy or sell orders required to cause a certain price change. If abundant orders exist around the currently traded price, a market is considered to be deep. A lack of depth may result in price discontinuities and uncertainty about equilibrium prices (Sarr and Lybek 2002). Resilience measures the time that is needed for the price to recover from an uninformative supply or demand shock, i.e., the time to turn back to its fundamental value. Two further dimensions of market liquidity, which have been introduced in the literature, are market breadth and immediacy (e.g., Ametefe et al. 2016). Breadth measures the size of the trading volume, while immediacy is defined as the speed at which a sell or buy order can be executed. Obviously, there is a trade-off between the time delay and cost of a trade.

It is commonly acknowledged that no single indicator can capture all of the aforementioned aspects. Ametefe et al. (2016) provide an overview about liquidity measures that have been suggested in the literature. They distinguish between measures that are based on transaction costs, trading volume, trading time, price impacts, or returns. A standard measure for roundtrip costs, i.e., the costs of purchasing and selling an asset in a short period of time, is the bid-ask 
spread. It is basically defined as the difference between the ask and bid quote and addresses market tightness (e.g., Amihud and Mendelson 1986). Volume-based measures target the depth and breadth of liquidity. The number of transactions or the traded volume, for example, belong to this class of indicators. A frequently used relative measure is the turnover that relates trading volume to total market size.

Immediacy can be captured by time-based measures, such as the time on market. Another time-based measure is trading frequency, which is the number of trades executed within a specific interval, regardless of volume. Moreover, the average holding period measures the time between the purchase and sale. It is related to the magnitude of transaction and trading costs, as higher costs are associated with longer periods. As this relation is difficult to grasp by data, the volume or inverse of turnover is used as a proxy for this indicator (Ametefe 2016, Atkins and Dyle 1997, Hess 1991). Duration is another indicator that can represent immediacy (Ametefe 2016). This indicator captures the time between two consecutive transactions. It can also measure the time it takes for a particular volume to be traded.

Price impact measures are motivated by the idea that in frictionless markets, trading activities should not change the equilibrium price of an asset unless new information about the fundamental value arrives. A prominent example of this group of indicators is the Amihud (2002) measure that relates the price change of an asset to the trading volume and thus is informative about market resilience. Return based measures pursue a similar idea. Information efficiency of a market implies that return series are stationary and serially uncorrelated. This can be verified, for example, by studying the run length of returns, which are defined as the consecutive series of positive or negative returns (Das and Hanouna 2010).

Many of the proxies commonly used to measure liquidity of stock and bond markets are not applicable to farmland markets or other real estate markets because trading in these markets does not take place on exchanges due to the heterogeneity. Thus, bid and ask quotations are not available and liquidity measures that refer to these data, such as the bid-ask-spread, cannot be calculated. Even if transaction data on farmland sales were available, they can hardly be used to calculate price changes and returns because individual land plots differ in their price determining attributes (e.g., quality, size, and location). For this reason, we focus on volume-based and time-based liquidity measures in the subsequent empirical application. The fact that farmland is traded on search markets rather than on exchanges entails another practical problem: It is not clear what the relevant market is for which the liquidity indicators should be determined. Apparently, volume-based liquidity indicators will depend on the regional size of the market and thus cross-sectional studies referring to administrative units have to account for variations in market size.

\subsection{Determinants of Liquidity}

The determinants and impact of liquidity in financial markets have been examined thoroughly, both theoretically and empirically (Amihud et al. 2005, Chordia et al. 2005). However, most market microstructure models explaining liquidity in financial markets are not directly applicable to real estate and land markets because they assume the existence of market makers as liquidity providers (e.g., Kyle 1985, Glosten and Milgrom 1985). Han and Strange (2015) emphasize three important features of real estate markets. First, real estate markets have extreme heterogeneity with regard to their characteristics, which results in market 
thinness. Second, potential buyers and sellers have to search for each other and once they meet, there is uncertainty about the willingness to pay and willingness to accept. Third, considerable market frictions exist that are manifested in search and transaction costs. A consequence of these features is that land and real estate markets clear not only through price, but also through time. Fisher et al. (2003) investigate liquidity in real estate markets using a search model with heterogeneous assets and market agents. In their model, transactions occur more frequently the more the distributions of reservation prices for buyers and sellers overlap. Fisher et al. (2003) argue that the distributions of reservation prices evolve differently for potential buyers and sellers in response to changing market conditions. Assuming that shifts in the reservation price distribution are more pronounced for buyers than for sellers, leads to a pro-cyclical behavior of market liquidity and prices: In booming markets, liquidity and prices go up, whereas the opposite holds true in down markets. Fisher et al. (2004) confirm this hypothesis empirically by means of a probit model. They find that apart from market conditions, ownership characteristics and property characteristics also significantly influence transaction frequency. In contrast, Mei (2018) reports that prices do not influence transaction frequency when applying a similar model to timberland markets in the U.S. Related to market depth in agricultural land markets, Ritter et al. (2020) find that large plots that are more than 160 hectares sell at a considerable discount in East Germany, which can be explained by a very low number of potential buyers that can afford to buy such a large amount of land.

The relation between prices (or returns) and market liquidity in real estate markets is addressed by two strands of literature (Wheaton and Lee 2008). Wheaton (1990) and Bercovec and Goodman (1996) employ search friction models to show that transaction volume affects asset prices. The reason for this effect is that, if a high rate of successful trades is observed, sellers adjust their reservation prices upwards. When assuming financial constraints of property owners or loss aversion of sellers, Stein (1995) and Engelhardt (2003) find an opposite causal direction between transaction volume and prices. Clayton et al. (2010) investigate the causal direction between prices and trading volume in the U.S. housing market. Using Granger causality tests, they find a "causal" relationship in both directions and conclude that the positive correlation between prices and trading volume can be explained by a co-movement of these two variables that are caused by shocks from exogenous variables.

Another determinant of market liquidity, sometimes labelled as 'clientele effects', are liquidity policies of market agents (Amihud et al. 2005). Different types of investors may have different holding periods for a financial asset, which, in turn, determine the demand for short-term sales. In the context of agricultural land markets, this aspect comes into play because of the increased engagement of non-agricultural investors in the aftermath of the financial crisis in 2008 (cf. Croonenbroeck et al. 2020). Non-agricultural investors are assumed to have a shorter holding period compared with farmers who utilize land as a production factor and usually pursue a buy-and-hold strategy. Thus, we expect higher liquidity in land markets where the share of non-agricultural investors is large.

Turvey (2003) provides an important contribution to the understanding of potential buyers' and potential sellers' reservation prices for agricultural land. He employs a real options framework to explain the reluctance to buy or sell land. In light of the uncertainty about future returns from land, sellers (buyers) require a lower (higher) rent-price ratio before they optimally decide to sell (buy) land. The value of waiting drives a wedge between the classical investment and 
disinvestment thresholds. This shift in reservation prices reduces the likelihood of a transaction. The reluctance to (dis)invest increases with increasing uncertainty about land sales and rental prices. It is difficult to test this theory empirically, however, it appears natural to consider farm exits as an indicator for realized disinvestment decisions. Thus, farm exit rates can be useful to capture land supply shocks in empirical land market liquidity models.

\section{Empirical Analysis}

\subsection{Study Region and Data}

In our empirical analysis, we focus on the German federal state of Lower Saxony, located in northwest Germany. It is the second largest state in Germany in terms of agricultural land (2,579,900 hectares in 2019 (Destatis 2019)), plays an important role regarding agricultural production (5.6 billion $€$ in 2019), and contributes the largest share of the agricultural gross value added in Germany (20.5 \% in 2019) (ML-Niedersachsen 2020). In 2019, 12,506 hectares of the agricultural land in Lower Saxony were sold, which is the largest amount of any federal state in Germany (Destatis 2020). The average sales price was $38,182 €$ per hectare in 2019, which is the third highest after Bavaria and North Rhine-Westphalia. The large amount of transacted land and the high prices render Lower Saxony an interesting study area for our research questions. Moreover, Yang et al. (2017) show that different regions within Lower Saxony exhibit different price dynamics, which is useful when examining the relation between liquidity and prices. Finally, the heterogeneity in local farming structures in Lower Saxony, such as intensive dairy, livestock, and crop production, further contributes to the representativeness and validity of this federal state for our analysis.

The applied dataset was provided by the committee of land valuation experts in Lower Saxony (Oberer Gutachterausschuss für Grundstückswerte in Niedersachsen) and consists of nearly all sale transactions of arable land in Lower Saxony between 1990 and 2018. Transactions with unusual circumstances were excluded beforehand by land valuation experts. Furthermore, Wesermarsch county and independent cities (kreisfreie Städte) were excluded from the analysis due to a lack of data. For each transaction, the price, sold area, seller information (if the seller is a farmer), date of transaction, and allocation of the plot to a county (Landkreis) are available. Additionally, the exact day of the transaction and location at the municipality-level (Gemeinde) are available from 2005 to 2018.

The analysis of liquidity in the land market - which is a type of search market - requires the definition of the relevant market because some indicators depend on the regional size of the market. As mentioned above, administrative units provide a spatially explicit overview of liquidity indicators. The choice of the appropriate administrative units, i.e., county or municipality, as the relevant market is discussed in the literature. Temesgen (2014 cited in Saint-Cyr et al. 2019) notes for Brittany, France, that $75 \%$ of all sale transactions take place in the municipality where the farm is located. In contrast, Plogmann et al. (2020) report that in Brandenburg, Germany, almost half of farm's newly acquired (bought or rented) land is outside municipality borders. As a clear answer to this question seems to be difficult to derive, our descriptive analysis provides liquidity indicators for administrative units, counties, and municipalities. In the econometric analysis, only county-level data are applied in order to base 
the calculation of variables on enough observations. Moreover, fluctuations in the soil quality of transactions within one county are smoothed by averaging.

To calculate the turnover rate (the ratio of the volume sold to the total amount of arable land in a particular area), the total amount of arable land is needed. These data come from the statistical office in Lower Saxony (Landesamt für Statistik Niedersachsen). Data on the number of farm exits, which is included as an exogenous variable in the econometric analysis, are also retrieved from the statistical office in Lower Saxony.

\subsection{Descriptive Analysis}

Measuring liquidity in the agricultural land market is based on volume- and time-based indicators, as explained in Section 2. Volume-based measures target the depth and breadth of liquidity. These dimensions are represented by the number of transactions, volume, and turnover. Time-based measures capture the dimension of immediacy with respect to liquidity. These measures are reflected in the duration between two consecutive transactions in days, duration until a particular volume is traded ( 1 hectare in our analysis) in days and trading frequency, i.e., the number of sales within a given period of time (1 year in our analysis).

Table 1 illustrates their relation by displaying different liquidity indicators for Lower Saxony as a whole and for each county separately for the observation period. In Lower Saxony, 72,547 transactions occurred from 1990 to 2018, with 171,384 hectares transacted. The annual average turnover is $0.34 \%$. The trading frequency is on average $2,501.62$ transactions per year and there are on average 0.15 days between each transaction and 0.06 days until the transaction of one hectare. This indicates a small level of liquidity, but there is noticeable variation between counties. The number of transactions for the observation period ranges from 261 (Wittmund) to 6,445 (Göttingen) transactions and the volume ranges from 757.50 hectares (Wittmund) to 13,537.11 hectares (Diepholz). The highest yearly amount of turnover is in Aurich $(0.68 \%)$ and the lowest in Region Hannover $(0.14 \%)$. Regarding the time-based indicators, the trading frequency ranges from 9 (Wittmund) to 222.24 (Göttingen) transactions, whereas the number of days until a hectare is sold ranges from 0.78 days in Diepholz to 13.98 days in Wittmund. Thus, the various indicators depict differences in their size and ranking across counties. 
Table 1: Liquidity indicators (1990-2018)

\begin{tabular}{|c|c|c|c|c|c|c|}
\hline County & $\begin{array}{l}\text { Number of } \\
\text { transactions }\end{array}$ & $\begin{array}{l}\text { Transaction } \\
\text { volume (ha) }\end{array}$ & $\begin{array}{l}\text { Turnover } \\
\text { (\%/year) }\end{array}$ & \begin{tabular}{|c|} 
Trading \\
frequency \\
(per year)
\end{tabular} & $\begin{array}{c}\text { Duration } \\
\text { (days/ } \\
\text { transaction) }\end{array}$ & $\begin{array}{l}\text { Duration } \\
\text { (days/ha) }\end{array}$ \\
\hline & \multicolumn{3}{|c|}{ Volume-based } & \multicolumn{3}{|c|}{ Time-based } \\
\hline Ammerland & 641 & $1,968.50$ & 0.40 & 22.10 & 16.52 & 5.38 \\
\hline Aurich & 2,110 & $6,215.99$ & 0.68 & 72.76 & 5.02 & 1.70 \\
\hline Celle & 1,097 & $3,532.21$ & 0.30 & 37.83 & 9.66 & 3.00 \\
\hline Cloppenburg & 2,265 & $7,628.35$ & 0.33 & 78.10 & 4.68 & 1.39 \\
\hline Cuxhaven & 2,400 & $6,729.79$ & 0.53 & 82.76 & 4.41 & 1.57 \\
\hline Diepholz & 4,990 & $13,537.11$ & 0.43 & 172.07 & 2.12 & 0.78 \\
\hline Emsland & 4,427 & $12,557.25$ & 0.32 & 158.11 & 2.39 & 0.84 \\
\hline Friesland & 280 & 812.74 & 0.22 & 9.66 & 37.83 & 13.03 \\
\hline Gifhorn & 1,594 & $5,627.31$ & 0.32 & 54.97 & 6.64 & 1.88 \\
\hline Goslar & 839 & $1,381.94$ & 0.23 & 28.93 & 12.62 & 7.66 \\
\hline Göttingen & 6,445 & $6,780.95$ & 0.41 & 222.24 & 1.64 & 1.56 \\
\hline $\begin{array}{l}\text { Grafschaft } \\
\text { Bentheim }\end{array}$ & 1,262 & $3,237.40$ & 0.27 & 43.52 & 8.39 & 3.27 \\
\hline $\begin{array}{l}\text { Hameln- } \\
\text { Pyrmont }\end{array}$ & 2,310 & $4,259.55$ & 0.42 & 79.66 & 4.59 & 2.49 \\
\hline Harburg & 1,311 & $3,371.23$ & 0.32 & 45.21 & 8.08 & 3.14 \\
\hline Heidekreis & 1,563 & $5,240.63$ & 0.37 & 53.90 & 6.78 & 2.02 \\
\hline Helmstedt & 1,449 & $3,532.68$ & 0.35 & 49.97 & 7.31 & 3.00 \\
\hline Hildesheim & 3,287 & $6,089.82$ & 0.33 & 113.34 & 3.22 & 1.74 \\
\hline Holzminden & 1,310 & $2,346.87$ & 0.41 & 45.17 & 8.09 & 4.51 \\
\hline Leer & 434 & $1,033.76$ & 0.29 & 14.97 & 24.41 & 10.25 \\
\hline $\begin{array}{l}\text { Lüchow- } \\
\text { Dannenberg }\end{array}$ & 2,169 & $5,578.27$ & 0.42 & 74.79 & 4.88 & 1.90 \\
\hline Lüneburg & 1,149 & $3,900.52$ & 0.28 & 39.62 & 9.22 & 2.72 \\
\hline $\begin{array}{l}\text { Nienburg } \\
\text { (Weser) }\end{array}$ & 4,800 & $11,042.67$ & 0.55 & 165.52 & 2.21 & 0.96 \\
\hline Northeim & 3,899 & $5,791.64$ & 0.42 & 134.45 & 2.72 & 1.83 \\
\hline Oldenburg & 1,519 & $5,447.28$ & 0.38 & 52.38 & 6.97 & 1.94 \\
\hline Osnabrück & 2,459 & $5,775.06$ & 0.19 & 84.79 & 4.31 & 1.83 \\
\hline Osterholz & 457 & 978.25 & 0.33 & 15.76 & 23.18 & 10.83 \\
\hline Peine & 1,861 & $2,895.09$ & 0.31 & 64.17 & 5.69 & 3.66 \\
\hline $\begin{array}{l}\text { Region } \\
\text { Hannover }\end{array}$ & 2,251 & $3,854.78$ & 0.14 & 77.62 & 4.71 & 2.75 \\
\hline $\begin{array}{l}\text { Rotenburg } \\
\text { (Wümme) }\end{array}$ & 3,024 & $8,552.93$ & 0.39 & 104.28 & 3.50 & 1.24 \\
\hline Schaumburg & 1,935 & $3,857.46$ & 0.46 & 66.72 & 5.47 & 2.75 \\
\hline Stade & 1,268 & $3,719.08$ & 0.36 & 43.72 & 8.35 & 2.85 \\
\hline Uelzen & 811 & $2,891.22$ & 0.15 & 27.97 & 13.06 & 3.66 \\
\hline Vechta & 1,462 & $3,843.27$ & 0.29 & 50.41 & 7.24 & 2.76 \\
\hline Verden & 1,584 & $3,740.75$ & 0.40 & 54.62 & 6.69 & 2.83 \\
\hline Wittmund & 261 & 757.50 & 0.20 & 9.00 & 40.58 & 13.98 \\
\hline Wolfenbüttel & 1,624 & $2,874.61$ & 0.21 & 56.00 & 6.52 & 3.68 \\
\hline Lower Saxony & 72,547 & $171,384.47$ & 0.34 & $2,501.62$ & 0.15 & 0.06 \\
\hline
\end{tabular}


To identify potential clusters, we now focus on the spatial representation of three liquidity indicators, namely the total number of transactions, turnover, and duration (displayed in Figure 1-3). As shown, liquidity is rather low, nevertheless there is heterogeneity. The total number of transactions, depicted in Figure 1, varies by municipality. Municipalities with a darker color indicate more transactions and thus higher liquidity. Not surprisingly, the number of transactions appears to be positively related to the size of the municipality. Along the southern border, large municipalities display the highest number of transactions (more than 80), whereas smaller municipalities located along the northeastern border exhibit a low number of transactions (less than 40). Yet, differences with regard to the liquidity indicator across samesized municipalities are observable. A horizontal belt in the central western part of Lower Saxony shows a heterogeneous picture with the number of transactions spread across categories in spatial proximity.

Figure 1: Total number of transactions at the municipality level (Lower Saxony, 20052018)

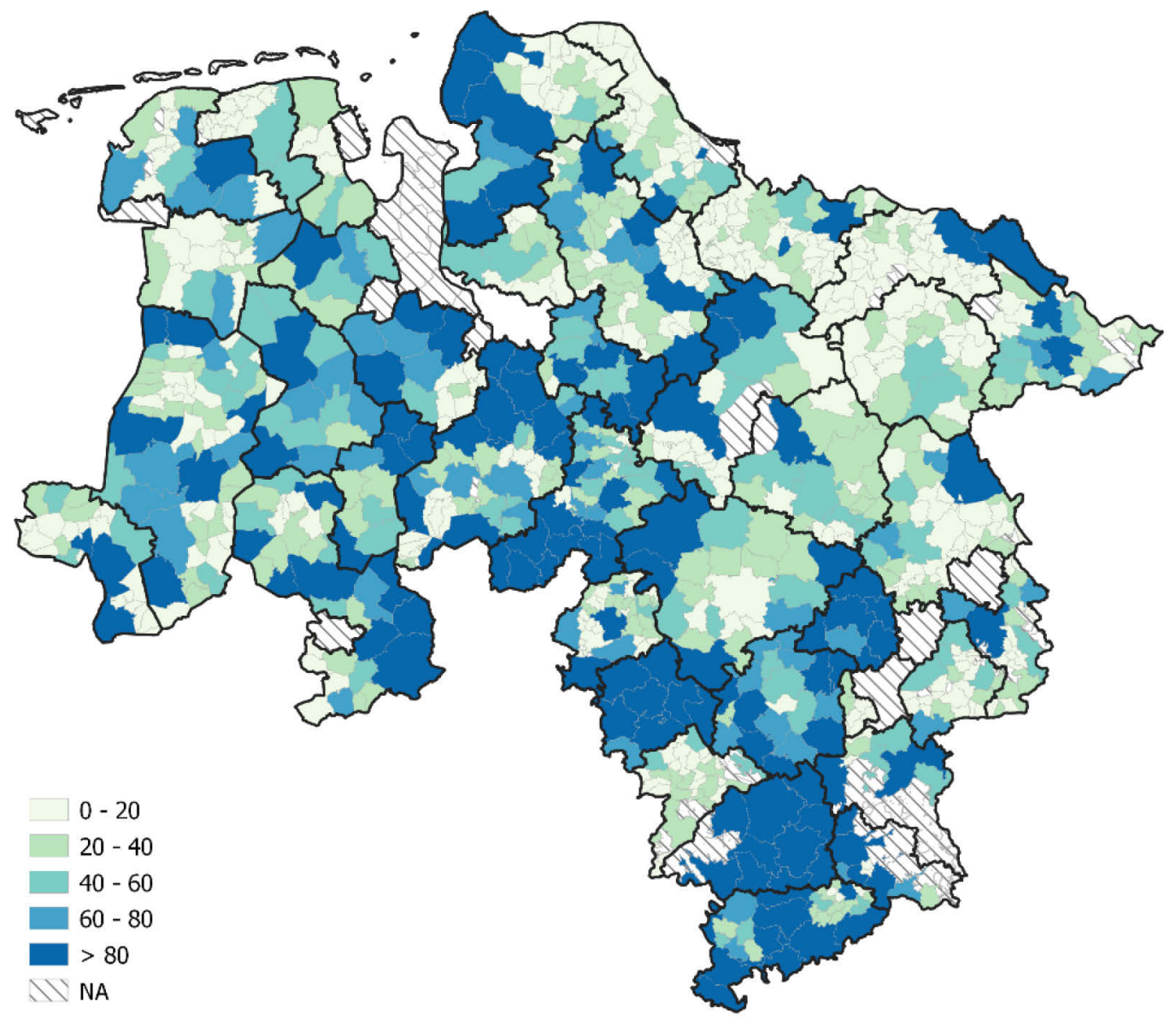

Turnover is an alternative volume-based indicator that accounts for the differences in municipality size. As shown in Figure 2, the majority of municipalities exhibit a median turnover of up to $0.4 \%$, yet there are still differences across regions that are observable. These regional patterns allow the grouping of municipalities at the county-level and further identify inter- county cluster. Southwestern and southeastern counties can be identified as a cluster with low turnover (0-0.2 \% and $0.2-0.4 \%)$ that exhibited a high number of transactions in Figure 1. The northern and central areas depict a more heterogeneous picture since there are turnover 
levels in all categories. Small municipalities in the northeast that had a particularly low number of transactions in Figure 1, now show a comparatively high turnover rate (above $0.8 \%$ ). In general, there are only a small number of municipalities that have a turnover rate above $0.8 \%$. This confirms the low level of liquidity.

Figure 2: Median annual turnover in percent at the municipality level (Lower Saxony, 2005-2018)

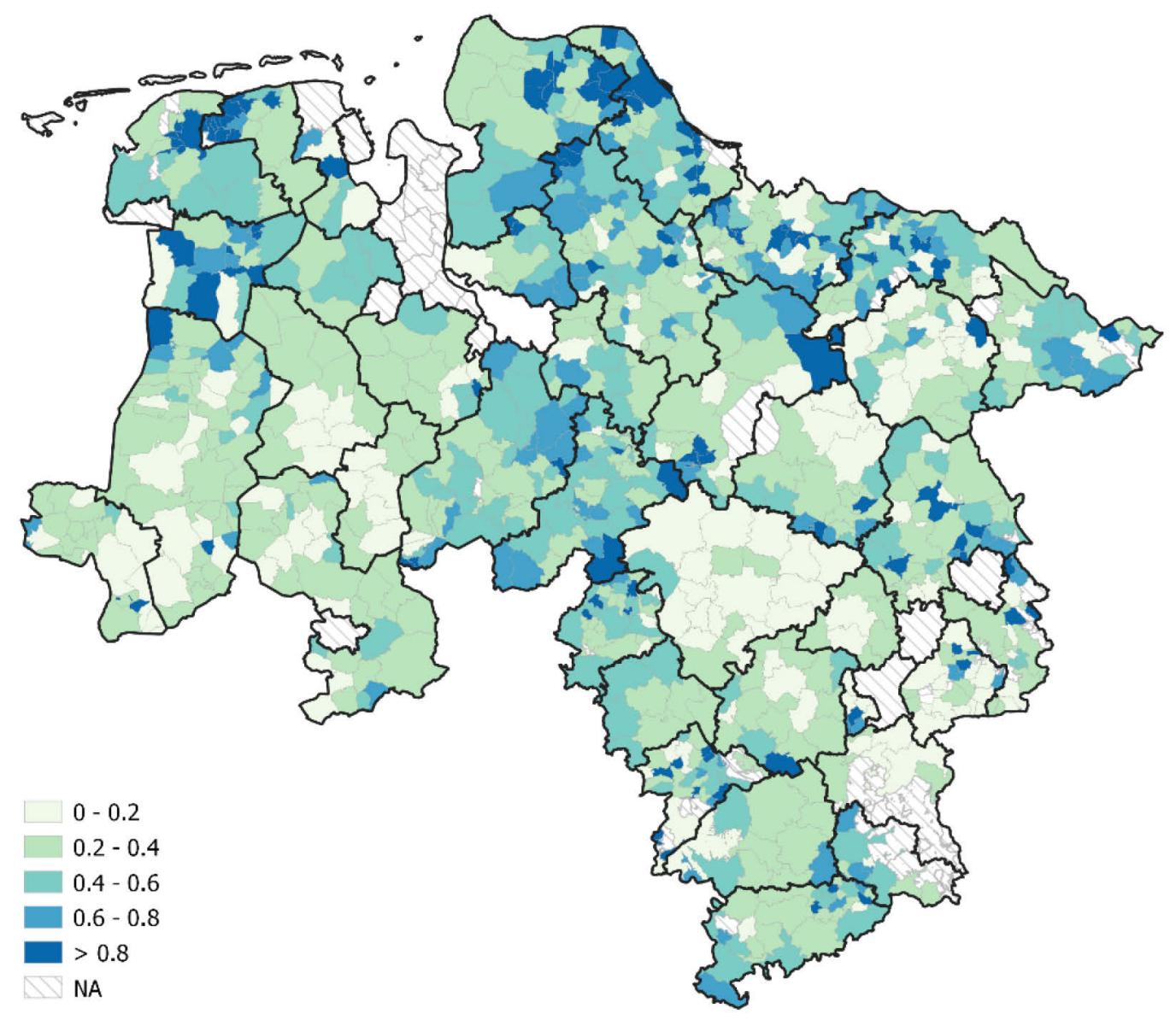

A different, but again heterogeneous picture, is given by the spatial distribution of the median duration until selling $0.1 \%$ of the total agricultural land located within a given municipality. This time-based liquidity indicator is a type of duration that captures the time it takes to sell a particular share of the market and is shown in Figure 3. The classification in months, which is a highly aggregated period of time, again indicates the slow-moving and thus thin market. Nevertheless, diverging patterns are identifiable. Counties located in the center of Lower Saxony form a cluster of short durations (up to two months and two to four months). This category extends to the northern and northwestern areas of Lower Saxony. Two hubs of counties with long durations (six to eight months or more than eight months) are shown; one is in the western part of Lower Saxony and the other is in the southeastern part. A more heterogeneous picture is especially given in the northeastern part where there are different durations in bordering municipalities. The spatial dimension of these three liquidity indicators allows the identification of different clusters of liquidity; some are more homogeneous and others are more heterogeneous. The closest administrative units that account for the size of these clusters are individual counties or are a group of counties. 
Figure 3: Median duration until selling $0.1 \%$ shown in months at the municipality level (2005-2018)

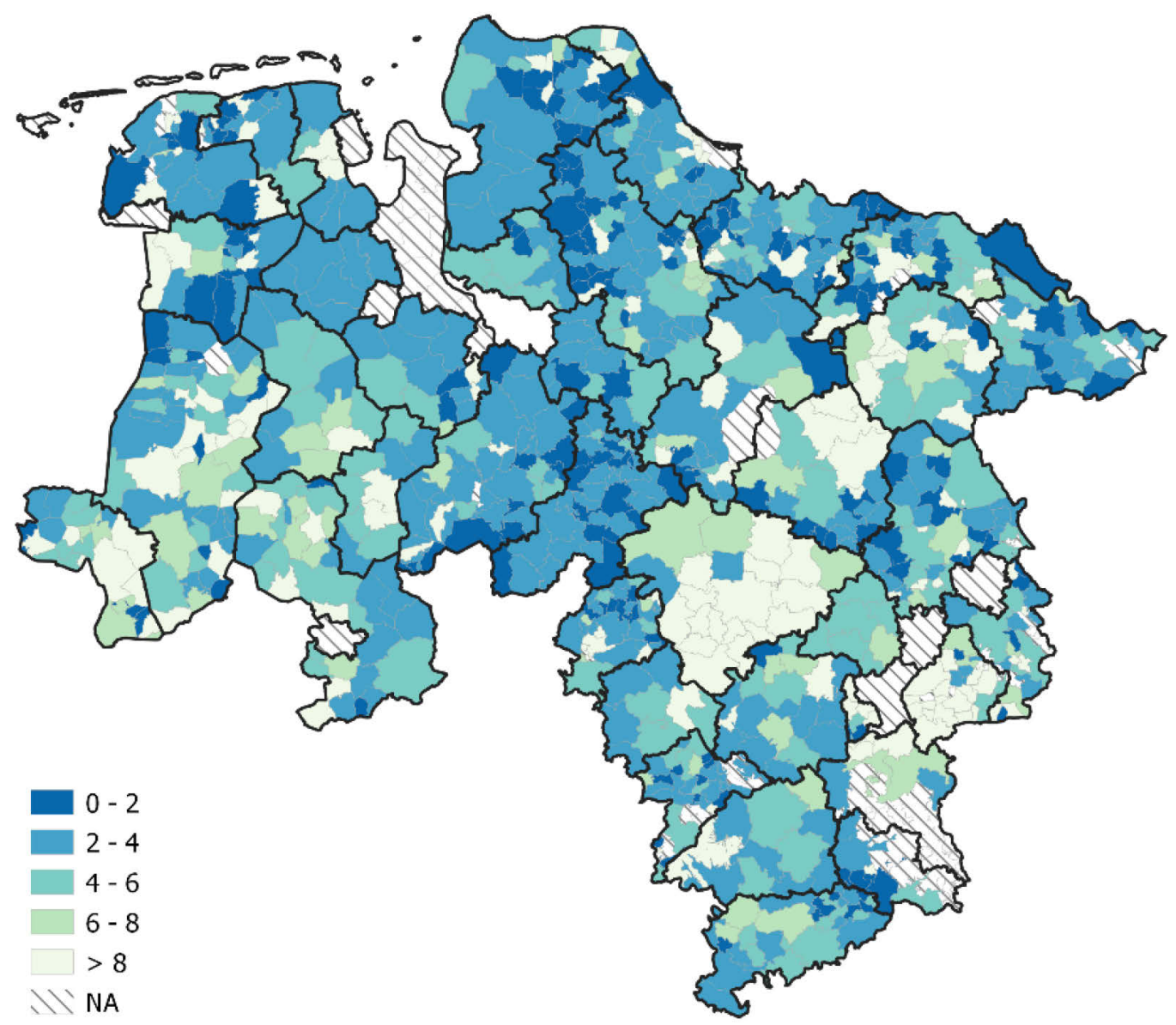

We now turn to the temporal development of the liquidity indicator turnover. The dynamics of turnover in Lower Saxony between 1990 and 2018 are depicted in Figure 4. Turnover in Lower Saxony displays a stable evolvement, ranging from $0.27 \%$ (in 2014) to $0.39 \%$ (in 1996), with a mean of $0.34 \%$. Neither trends, increasing or decreasing, nor cycles are observable. In contrast, the mean price per hectare in Lower Saxony follows a different development. The land price in Lower Saxony (also depicted in Figure 4) is rather stable until the financial crisis and then strongly increases until the end of the observation period. It covers a range from $13,588 €$ per hectare in 1994 to $40,525 €$ per hectare in 2018 . Thus, liquidity and land prices show diverging patterns. At first glance, no positive correlation between land prices and liquidity is observable, this is in contrast to findings in the real estate market (Stein 1995, Wheaton 1990). A closer inspection of this relationship and the time series properties of turnover and prices is conducted in the following section.

Figure 4 also illustrates the presence of heterogeneity in the temporal dimension of liquidity. Apparently, the level of turnover not only differs between counties on average, but there are also differences in the development of liquidity over time in regard to trend and volatility. In the Region Hannover, for example, turnover is rather stable and is at a low level with a mean of $0.14 \%$. Turnover in Friesland also exhibits a small mean $(0.22 \%)$, but is more volatile with a minimum of $0.002 \%$ in 2010 and a maximum of $0.61 \%$ in 2016 . A few counties show a decreasing tendency in turnover. For example, turnover in Aurich has a peak of $1.48 \%$ in 1995, 
and then has a downward trend with volatility, ending the observation period in 2018 at $0.29 \%$. Aurich has its minimum turnover in $2015(0.23 \%)$ and its average turnover $(0.68 \%)$ is the highest of all counties.

Figure 4: Mean turnover of farmland in selected counties and Lower Saxony (left-hand axis), mean price of farmland in Lower Saxony (right-hand axis) (1990-2018)

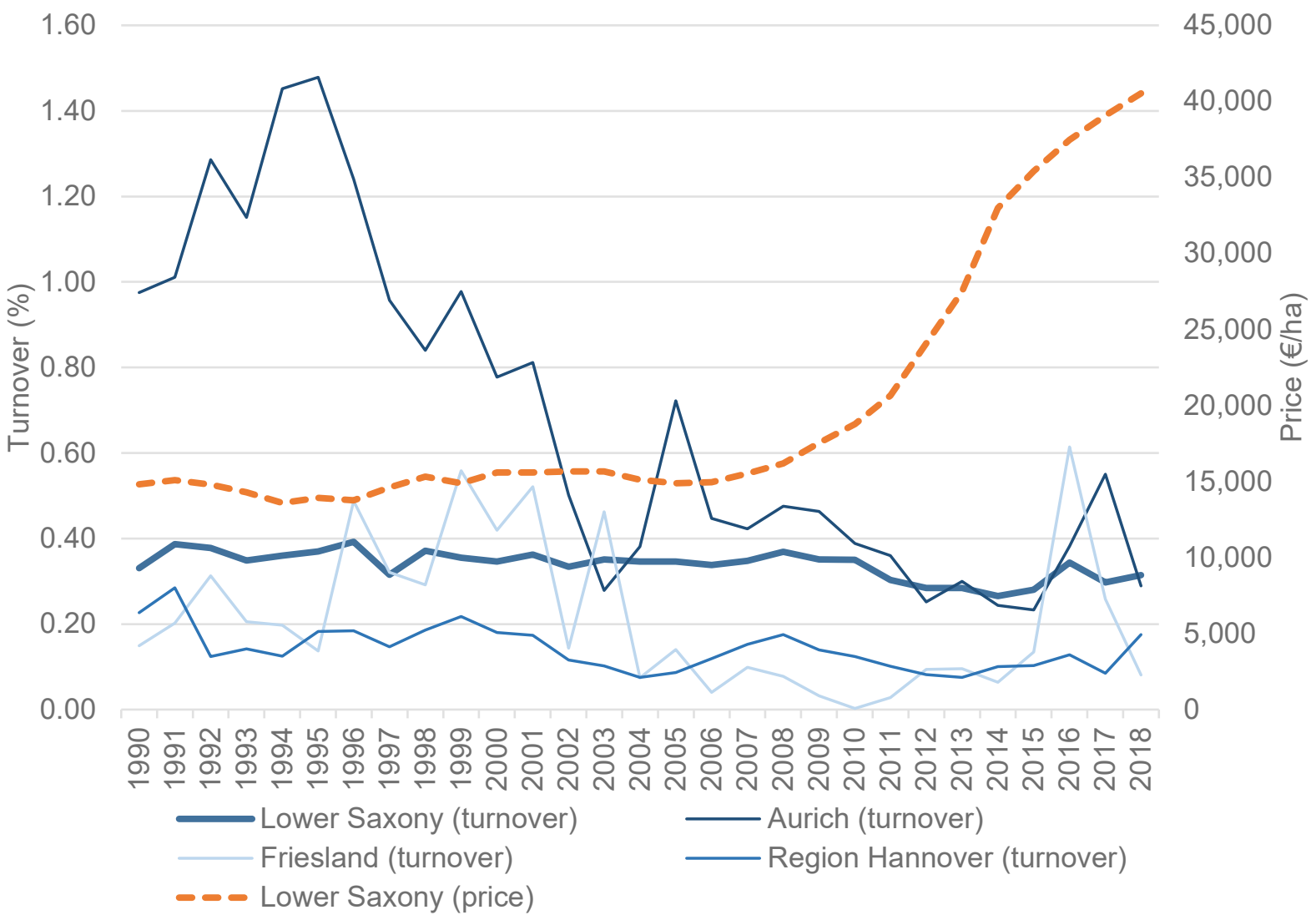

\subsection{Econometric Analysis}

\subsubsection{Model Specification}

A panel VAR model is applied to analyze the interplay of liquidity and prices in the agricultural land market. The choice of a panel VAR model presents clear benefits for answering the research question. First, a VAR approach allows us to adapt an explorative approach in regards to the relation between market liquidity and land prices, as well as to examine whether the direction of influence established in the real estate market literature (Wheaton 1990, Stein 1995) holds for agricultural land markets. Based on this model, we are able to directly apply Granger causality tests to investigate a lead-lag relationship between prices and liquidity. A lead-lag relation appears reasonable for the thin and slowly adapting land market. Second, the model further permits us to introduce exogenous covariates as potential determinants of turnover and prices on the land market to expand the information set of the analysis. Finally, the graphical analysis suggests spatial heterogeneity, which calls for a panel approach. A panel VAR model is thus able to account for the characteristics of agricultural land markets and for examining the interplay of liquidity and prices. 
We specify the following bivariate panel VAR model:

$$
\left(\begin{array}{c}
p_{i, t} \\
q_{i, t}
\end{array}\right)=\left(\begin{array}{c}
a_{i} \\
b_{i}
\end{array}\right)+\sum_{l}^{L} B_{l}\left(\begin{array}{c}
p_{i, t-l} \\
q_{i, t-l}
\end{array}\right)+C X_{i, t}+\left(\begin{array}{c}
\varepsilon_{i, t}^{p} \\
\varepsilon_{i, t}^{q}
\end{array}\right)
$$

where $i$ denotes the county in period $t, l$ denotes the lag, $p_{i, t}$ denotes the log of the price, and $q_{i, t}$ denotes turnover. $p_{i, t-l}$ and $q_{i, t-l}$ indicate the log price and turnover for the $i$ th county for the lth lag, respectively. $X_{i, t}$ is a $k \times 1$ vector of exogenous variables and $\varepsilon_{i, t}^{p}$ and $\varepsilon_{i, t}^{q}$ are the error terms. $B_{l}$ is a $2 \times 2$ vector and $C$ is a $2 \times k$ vector.

Before applying the model, we continue our analysis by testing the characteristics of the time series of prices and turnover. We begin by detecting potential structural breaks. The null hypothesis of no structural break in the Chow test cannot be rejected for the vast majority of counties (34 out of 36 counties for turnover and 33 out of 36 for returns). Furthermore, the panel VAR requires stationarity for the time series to avoid spurious regression. To account for the panel structure of the model, a panel unit root test is applied. The general structure of a panel unit root test is based on the univariate Augmented Dickey Fuller test, but captures the different time series in the panel. The Im-Pesaran-Shin (IPS) test formulates the null hypothesis of all of the time series having a unit root, whereas the alternative hypothesis allows heterogeneity, namely that at least one of the time series is stationary. As expected, the null hypothesis cannot be rejected for prices, indicating that they are not stationary. Thus, we take the first-order difference of the log prices, i.e., we use log returns. ${ }^{1}$ In contrast, the turnover is taken in levels since the null hypothesis of no stationarity can be rejected at the $5 \%$ significance level. That is, differencing of endogenous variables takes place upon need (Andrew and Meen 2003, Wheaton and Lee 2008).

To determine the lag $l$, a lag specification test based on the Akaike Information Criterion (AIC) is applied. It suggests a lag of one for the majority of counties, which is in accordance with empirical applications analyzing the turnover-price relation (Clayton et al. 2010). The lagged endogenous variable in the panel VAR constitutes a dynamic model. In such cases, the generalized method of moments (GMM) estimator developed by Arellano and Bond (1991) is a commonly used estimator. However, it requires differencing and thus sample information is lost, rendering the results less accurate. An alternative approach is so-called "partial pooling", which is particularly applicable when there is a moderate size of $T$ and $N$ (Swamy 1970). The partial pooling approach can be regarded as a random coefficient model, which is estimated by feasible generalized least squares (FGLS). This estimator establishes a framework that deals with serial correlation and intragroup heteroskedasticity because the variancecovariance matrix is unrestricted in every county and robust against both. Applying FGLS provides estimates of average coefficients, rather than individual county coefficients. This restriction, however, is not severe, as determinants of market liquidity and returns established in the literature are general and should apply to all counties.

To exploit the panel structure of the model, the panel Granger non-causality test by Dumitrescu and Hurlin (2012) is conducted. This test is based on the individual Wald statistic of Granger non-causality and uses cross-sectional information to improve the specification and power of

1 According to Stein (1995) and Wheaton and Lee (2008), the relationship between liquidity and prices established in the real estate literature also holds for liquidity and returns. 
the test. The average Wald statistic $\bar{W}$ is computed and used to derive the standardized test statistic $\tilde{Z}$. A homogeneous non-causality hypothesis underlies the test. The null hypothesis assumes that no causal relationship exists for any units of the panel, whereas the alternative hypothesis refers to the causality for some, but not necessarily all, individuals. As a feedback system is possible, both directions of influence between turnover and return are tested.

Granger causality is sensitive to the proper specification of the time series model. Being a statistical concept that underlies a given, pre-specified, and necessarily restricted information set, the results are very sensitive to its composition (Grosche 2014). In reality, the condition that all relevant information in the universe is included in the information set is not fulfilled, as it only includes the two lagged variables. Thus, wrong variable specification and omitted variable bias may affect the test results. No robust conclusion about the absence or presence of Granger causality can be made and the concept exhibits a limited potential for isolated application. Granger causality is thus suitable for a prima facie evidence of causal relationships. The information set should be extended by further market variables that might be determinants of liquidity and prices. In this context, the concept of conditional Granger causality could facilitate the analysis of whether a given interaction between two time series is direct or is instead mediated by another variable.

Rather than applying conditional Granger causality, we include exogenous covariates as further market variables into the panel VAR. Identified as determinants of market liquidity in the literature, farm exits and the share of agricultural sellers are included in the equation. Farm exit is commonly defined as the amount of farmland in hectares that have been exited in a given timeframe. Unfortunately, this data is not available for our analysis. Thus, we choose an alternative approach that is in line with the scope of the data: We define farm exit as the change in the absolute number of farms relative to the agricultural land in hectares. Once again, the latter part is important to account for different county sizes. This variable represents a supply shock of land becoming available for sale and may ultimately influence market liquidity and returns. The share of agricultural sellers constitutes a proxy for the different types of landowners since better sources, such as landowner registers, are not publicly available for confidentiality reasons. Sellers are differentiated between agricultural actors, i.e., practicing farmers and non-agricultural actors. The share of agricultural sellers is calculated by a volumeweighted approach based on transactions in which seller information is available.

Table A1 in the appendix displays the annual mean of the variables included in the panel VAR. Regarding the two exogenous variables, it shows differences across counties. Farm exit has a minimum of 63.96 farms in Lüneburg and a maximum of 210.62 farms in Osnabrück. The share of agricultural sellers ranges from $14.68 \%$ in Göttingen to $86.62 \%$ in Helmstedt.

\subsubsection{Results and Discussion}

Table 2 displays the results of the VAR estimation with and without covariates. First, we turn to the results without covariates, which reflect the unconditional relationship between liquidity and returns. Granger causality tests are based on this specification. The stability of the panel VAR estimates is given since the modulus of the eigenvalues of the coefficient matrix are below one. For both endogenous variables, we find autocorrelations that are statistically significant at the $1 \%$ level. Regarding the turnover's own dependency, the effect size $(0.6541)$ is comparatively large and a positive relationship is depicted. It contradicts the negative sign in 
the real estate literature, which implies reverse liquidity in the following year (Clayton et al. 2010). In contrast to turnover, the autocorrelation of returns is negative and in line with results from the real estate literature (Clayton et al. 2010). Negative autocorrelation implies that shortterm deviations are offset in the following period (Yang et al. 2019). Negative autocorrelation of returns is also observed in financial markets, albeit for different reasons, such as bid-askbounce or traders' overreaction to each other's trade during high trading-time (French and Roll 1986). However, the effect size is not large (-0.2931). Overall, the low $R^{2}(0.09)$ of the return equation confirms the well-known fact that returns are hardly predictable.

Table 2: Estimation of panel VAR with and without covariates

\begin{tabular}{|c|c|c|c|c|c|c|c|c|}
\hline & \multicolumn{4}{|c|}{ Model I } & \multicolumn{4}{|c|}{ Model II } \\
\hline & \multicolumn{2}{|c|}{ Turnover } & \multicolumn{2}{|c|}{ Return } & \multicolumn{2}{|c|}{ Turnover } & \multicolumn{2}{|c|}{ Return } \\
\hline & Coef. & St.err. & Coef. & St.err. & Coef. & St.err. & Coef. & St.err. \\
\hline Intercept & $0.1158^{* \star \star}$ & * 0.0052 & $0.0614^{* * *}$ & ${ }^{*} 0.0025$ & $0.1029^{\star * \star}$ & 0.0063 & $0.0818^{* * *}$ & 0.0046 \\
\hline Turnover lag 1 & $0.6541^{* * *}$ & * 0.0102 & $-0.0390^{* * *}$ & ${ }^{*} 0.0064$ & $0.6469^{\star * *}$ & 0.0115 & $-0.0199^{* * *}$ & 0.0075 \\
\hline Return lag 1 & $-0.0402^{* * \star}$ & * 0.0107 & $-0.2931^{* * *}$ & * 0.0146 & $-0.0409^{* * *}$ & 0.0121 & $-0.3136^{\star * *}$ & 0.0144 \\
\hline Farm exit & - & - & - & - & $7.7980 \mathrm{e}-05^{\star \star \star}$ & $1.3869 \mathrm{e}-05$ & $-0.0002^{\star * *}$ & $1.2837 \mathrm{e}-05$ \\
\hline Share of agri. sellers & - & - & - & - & $8.1604 \mathrm{e}-05$ & $6.6472 \mathrm{e}-05$ & $0.0001^{* * *}$ & $5.0294 \mathrm{e}-05$ \\
\hline Adj. $R^{2}$ & 0.4274 & & 0.0904 & & 0.4292 & & 0.1161 & \\
\hline
\end{tabular}

Note: ${ }^{* * *}$ denotes statistical significance at the $1 \%$ level.

The panel VAR results also depict the relationship between market liquidity and returns, which is even more important in light of our research questions. For both turnover and returns, a negative relationship is identified. The null hypotheses of no effect are rejected at the $1 \%$ level, yet effect sizes are small $(-0.040$ and -0.039 , respectively). These findings are only partly confirmed by the results of the Granger causality test. The null hypothesis of no Granger causality can be rejected for turnover causing returns $(\tilde{Z}=4.971, \mathrm{p}$-value $=6.661 \mathrm{e}-07)$. However, the null hypothesis cannot be rejected for the reverse relationship, i.e., that returns Granger-cause turnover $(\tilde{Z}=0.7042$, p-value $=0.4831)$. When interpreting these results, two points are notable.

First, the diverging significance between the panel VAR and Granger causality results is puzzling because the Granger causality test is based on the panel VAR model. Thus, Granger causality results should display a feedback mechanism in accordance with the panel VAR results. The reason for the observed divergence might be traced back to differences in the implementation of the panel approach in both applications. The panel VAR and panel Granger causality test pool data at different points in their estimation. Repeating the analysis for the time series of turnover and return aggregated for Lower Saxony as a whole, supports this potential explanation.

The second notable result is that the negative relation between turnover and returns in both directions contrasts the majority of findings in the real estate market literature, which is described in Section $2 .^{2}$ This is perhaps not too surprising because the arguments provided

2 An exception is the negative reaction of sales in the market to price movements found in a working paper by Wheaton and Lee (2008). 
for a positive correlation between prices and market liquidity in housing markets cannot be easily transferred to agricultural land markets. Down payments hindering property owners to purchase new property in case of falling prices are uncommon in the land market. Loss aversion may prevail in land markets as well, however, there were no pronounced phases of price decline in the observation period. Furthermore, the matching model developed for the housing market, which shows that liquidity influences prices, assumes that owners stay in the lifecycle of the property by passing from one property to another. In the land market, however, sellers leave the market. Finally, even though the real estate literature does not differentiate between prices and returns with respect to their relation to liquidity, one should recall that despite being closely related, they show different temporal developments. This may lead to the absence of a positive relationship between turnover and returns.

Model II displays the results of the panel VAR model including the share of agricultural sellers and farm exit as exogenous variables. The estimates for the lagged endogenous variables show similar signs and sizes, thus displaying the robustness of the results. The added exogenous covariates increase the explanatory power of the models only slightly $\left(R^{2}=0.4292\right.$ for turnover and $R^{2}=0.1161$ for returns). The share of agricultural sellers shows a positive sign with respect to its effect on turnover. The effect size is small $(8.16 \mathrm{e}-05)$ and the null hypothesis of no effect cannot be rejected at the $5 \%$ significance level. The estimation of this clientele effect is hampered by the definition of the variable, which only serves as a proxy for the landowners' aspiration or reluctance to sell land more frequently. The non-agricultural sellers form a very heterogeneous group, as they include private persons, corporations, and public institutions. Thus, assumptions about their trading behavior are difficult to derive. Regarding the influence of farm exits on turnover, the null hypothesis of no effect can be rejected at the $1 \%$ significance level. Farm exits enhance the turnover on regional land markets as they constitute a positive land supply shock. The effect size, however, is small (7.79e-05). This may be explained by the absorption of the effect by the rental market before the sales market. Returns are negatively influenced by farm exit and positively influenced by the share of agricultural sellers. The null hypothesis of no effect can be rejected for both variables at the $1 \%$ significance level. With increasing farm exits, more available land is released into the market, and with demand remaining constant, returns decrease. Furthermore, the results display that the larger the share of agricultural sellers, the higher the return. This might relate to the diverging valuation of land between agricultural and non-agricultural investors. The very small size of the coefficients for both farm exit and the share of agricultural sellers $(-0.0002$ and 0.0001 , respectively) as well for the lagged endogenous variables is reflected in the small $R^{2}$.

\section{Conclusions}

This paper is one of the first attempts to empirically explore liquidity in agricultural land markets in greater detail. Based on a brief review of liquidity dimensions and their measurement in financial markets, we select several indicators that are useful for and applicable to land markets, namely the number and volume of transactions, turnover, trading frequency, and duration. These indicators are related, but nevertheless convey different information about land markets' liquidity. In contrast to financial markets, a proper normalization is necessary to account for differences in the regional market size. Though our study is primarily explorative, we review the theoretical and empirical literature on liquidity in real estate markets to derive 
hypotheses and expectations. Land and real estate markets share some important features, i.e., immobility, heterogeneity, and market frictions due to high search and transaction costs.

The empirical analysis is conducted for Lower Saxony, the federal state with the highest agricultural production value in Germany, as well as diverse farm structures and production systems. This heterogeneity also holds for the liquidity of regional land markets, at least in relative terms. The turnover of arable land amounts to an average of $0.34 \%$ per year at the state-level, while at a county-level the largest average annual turnover is 4.8 times higher than the smallest one. Other indicators confirm differences in the liquidity of regional land markets. To some extent, these differences also apply to the development of market liquidity over time. Some counties in Lower Saxony show a positive or negative trend in liquidity indicators, though most counties and the state average do not exhibit trends. This is noteworthy because the observation period covers a phase of soaring land prices. In contrast to empirical findings from the housing market, no positive correlation between market liquidity and prices could be observed. This finding is confirmed by the results of a panel VAR and a related Granger causality test. Also, the (non-)agricultural background of market participants does not appear to play an important role for the intensity of transactions in the land market. Solely the number of farm exits in a region could be identified as a determinant with a positive effect on land market turnover. Overall, land market liquidity appears to follow a stationary and hence meanreverting stochastic process that returns rather promptly to a "natural", county-specific level of transactions after land supply shocks occur. The stochasticity of liquidity indicators vanishes at an aggregated market level. This suggests that land markets are more of a seller's market, in which supply shocks are absorbed by a steady and high demand from expanding farms, irrespective of the prevailing price level or market phase. Trading strategies that immediately respond to price changes, such as in financial markets, appear to be less relevant.

Our analysis is a first and important step in understanding liquidity in agricultural land markets. The reduced-form modelling approach chosen for this analysis is silent about determinants of the observed regional heterogeneity in market liquidity. It would be interesting to explore in greater detail why counties differ in frequency and volume of land market transactions. Tradition, experience, farm size structure, and production structure may be factors. Moreover, our VAR model investigates the time series properties of turnover and land prices at an aggregated level. Thus, the impact that market thinness may have on prices of individual plots cannot be identified. This requires a microstructural analysis based on transaction data in which market thinness can be separated from other price determinants, such as land amenities and characteristics of buyers and sellers. Curtiss et al. (2021) propose a modified hedonic pricing model that enables the decomposition of land price determinants by means of a stochastic frontier model. The incorporation of liquidity indicators in this model would be a promising direction for further research. 


\section{References}

Adämmer, P., Bohl, M.T., Gross, C. (2016): Price Discovery in Thinly Traded Futures Markets: How Thin is Too Thin? Journal of Futures Markets 36(9): 851-869.

Admati, A.R., Pfleiderer, P. (1988): A Theory of Intraday Patterns: Volume and Price Variability, Review of Financial Studies, Society for Financial Studies 1(1): 3-40.

Ametefe, F., Devaney, A., Marcato, G. (2016): Liquidity: Review of Dimensions, Causes, Measures, and Empirical Applications in Real Estate Markets. Journal of Real Estate Literature 24(1): 1-29.

Amihud, Y (2002): Illiquidity and stock returns: Cross-section and time-series effects. Journal of Financial Markets 5(1): 31-56.

Amihud Y., Mendelson H. (1986): Asset Pricing and the Bid-Ask Spread. Journal of Financial Economics 17(2): 223-249.

Amihud, Y., Mendelson, H. (2006): Stock and bond liquidity and its effect on prices and financial policies. Financial Market and Portfolio Management 20(1): 19-32.

Amihud, Y, Mendelson, H, Pedersen, L.H. (2005): Liquidity and Asset Prices. Foundations and Trends in Finance 1(4): 269-364.

Andrew, M., Meen, G. (2003): House Price Appreciation Transactions and Structural Change in the British Housing Market: A Macroeconomics Perspective. Real Estate Economics 31(1): 99-116.

Arellano, M., Bond, S. (1991): Some Tests of Specification for Panel Data: Monte Carlo Evidence and an Application to Employment Equations. The Review of Economics Studies: 58(2): 277-297.

Atkins, A., Dyl, E. (1997): Transactions Costs and Holding Periods for Common Stocks. Journal of Finance 52(1): 309-325.

Berkovec, J.A., Goodman, J.L. Jr. (1996): Turnover as a Measure of Demand for Existing Homes. Real Estate Economics 24(4): 421-440.

Bigelow, D., Borchers, A., Hubbs, T. (2016): U.S. Farmland Ownership, Tenure, and Transfer. USDA Economic Information Bulletin No. (EIB-161): 1-53.

Bigelow, D. P., Ifft, J., Kuethe, T. (2020): Following the Market? Hedonic Farmland Valuation Using Sales Prices versus Self-reported Values. Land Economics 96(3): 418-440.

Black, F. (1971): Towards a fully automated exchange, part1. Financial Analysts Journal 27(4): 29-35.

Borchers, A., Ifft, J., Kuethe, T. (2014). Linking the price of agricultural land to use values and amenities. American Journal of Agricultural Economics 96(5): 1307-1320.

Chordia, T., Roll, R., Subrahmanyam, A. (2002): Market Liquidity and Trading Activity. The Journal of Finance 56(2): 501-530.

Chordia, T., Sarkar, A., Subrahmanyam, A. (2005): An Empirical Analysis of Stock and Bond Market Liquidity. The Review of Financial Studies 18(1): 85-129.

Clayton, J., Miller, N., Peng, L. (2010): Price-volume Correlation in the Housing Market: Causality and Co-movements. Journal of Real Estate and Financial Economics 40(1): 1440.

Cotteleer, G., Gardebroek, C., Luijt, J. (2008): Market power in a GIS-based hedonic price model of local farmland markets. Land Economics 84(4): 573-592.

Croonenbroeck,C., Odening, M., Hüttel, S. (2020) Farmland values and bidder behavior in firstprice land auctions. European Review of Agricultural Economics 47(2): 558-590.

Curtiss, J., Jelinek, L., Medonos, T., Hruska, M., Hüttel, S. (2021): Investors' Impact on Czech Farmland Prices: A Microstructural Investigation. European Review of Agricultural Economics (in print).

Das, S., Hanouna, P. (2010): Run Lengths and Liquidity. Annals of Operations Research 176(1): 127-152.

Destatis (2019). Bodennutzung der Betriebe (Struktur der Bodennutzung). Land- und Forstwirtschaft, Fischerei. Fachserie 3 Reihe 2.1.2.

https://www.statistischebibliothek.de/mir/receive/DEHeft mods 00124348 
Destatis (2020). Kaufwerte für landwirtschaftliche Grundstücke. Land- und Forstwirtschaft, Fischerei. Fachserie 3 Reihe 2.4. https://www.statistischebibliothek.de/mir/receive/DEHeft mods 00132409

Dumitrescu, E.-I., Hurlin, C. (2012): Testing for Granger Non-Causality in Heterogenous Panels. Economics Modelling 29(4): 1450-1460.

Engelhardt, G.V. (2003): Nominal loss aversion, housing equity constraints, and household mobility: Evidence from the United States. Journal of Urban Economics 53(1): 171-195.

Fisher, J., Gatzlaff, D., Haurin, D. (2003): Controlling for the Impact of Variable Liquidity in Commercial Real Estate Price Indices. Real Estate Economics 31(2): 269-303.

Fisher, J., Gatzlaff, D., Geltner, D., Haurin, D. (2004): An Analysis of the Determinants of Transaction Frequency of Institutional Commercial Real Estate Investment Property. Real Estate Economics 32(2): 239-264.

French, K.R., Roll, R. (1986): Stock return variances: The arrival of information and the reaction of traders. Journal of Financial Economics 17(1): 5-26.

Glosten, L.-R., Milgrom, P.R. (1985): Bid, ask and transaction prices in a specialist market with heterogeneously informed traders. Journal of Financial Economics 14(1): 71-100.

Graubner, M. (2018): Lost in space? The effect of direct payments on land rental prices. European Review of Agricultural Economics 45(1): 143-171.

Grosche, S.-C. (2014): What does Granger Causality Prove? A Critical Examination of the Interpretation of Granger Causality Results on Price Effects on Index Trading in Agricultural Commodity Markets. Journal of Agricultural Economics 65(2): 279-302.

Han, L., Strange, W.C. (2015): The Microstructure of Housing Markets: Search, Bargaining, and Brokerage. Handbook of Regional and Urban Economics, Volume 5: 813-886.

Hasbrouck, J., Seppi, D.J. (2001): Common Factors in prices, order flows, and liquidity. Journal of Financial Economics 59(3): 383-411.

Hess, A. (1991): The Effect of Transaction Costs on Households' Financial Asset Demands. Journal of Money, Credit and Banking 23(3): 383-409.

Hibbert, J., Kirchner, A., Kretschmar, G. McNeil, A. (2009): Liquidity Premium. Literature review of theoretical and empirical evidence. Research Report Barrie \& Hibbert Ltd.

Hüttel, S., Jetzinger, S., Odening, M. (2014): Forced Sales and Farmland Prices. Land Economics 90(3): 395-410.

Hüttel, S., Wildermann, L., Croonenbroeck, C. (2016). How do institutional market players matter in farmland pricing? Land Use Policy 59: 154-167.

Kuethe, T.H., Bigelow, D.P. (2018): Bargaining Power in Farmland Rental Markets. Selected Paper prepared for presentation at the 2018 Agricultural Applied Economics Association Annual Meeting, Washington, D.C., August 5-7, 2018.

Kyle, A. (1985): Continuous Auctions and Insider Trading. Econometrica 53(6): 315-1335.

Lence, S.H. (2001): Farmland Prices in the Presence of Transaction Costs: A Cautionary Note. American Journal of Agricultural Economics 83(4): 985-92.

Loughrey, J., Donnellan, T., Hanrahan, K. (2019): The Agricultural Land Market in the EU and the Case for Better Data Provison. EuroChoices 19(1): 41-47.

Mei, B. (2018): On the Determinants of Transaction Frequency of Institutional Commercial Timberland Properties in the United States. Land Economics 94(2): 206-219.

ML-Niedersachsen (2020). Die niedersächsische Landwirtschaft in Zahlen 2017 (Stand Mai 2020). Niedersächsisches Ministerium für Ernährung, Landwirtschaft und Verbraucherschutz.

https://www.ml.niedersachsen.de/download/150202/Die niedersaechsische Landwirtsc haft in Zahlen 2017 mit Ergaenzungen Stand Mai 2020.pdf

Nickerson, C. J., Zhang, W. (2014). Modeling the Determinants of Farmland Values in the United States. In: Duke, J.M. and Wu, J. (eds.): The Oxford Handbook of Land Economics. New York: Oxford University Press, 111-138.

Plogmann, J., Mußhoff, O., Odening, M., Ritter, M. (2020): Farm growth and land concentration. FORLand-Working Paper 24(2020). Humboldt-Universität zu Berlin. https://doi.org/10.18452/21399

Ritter, M., Hüttel, S., Odening, M., Seifert, S. (2020): Revisiting the relationship between land price and parcel size in agriculture. Land Use Policy 97: 104771. 
Saint-Cyr, L.D.F., Storm, H., Heckelei, T., Piet, L. (2019): Heterogeneous impacts of neighboring farm sizes on the decision to exit: Evidence from Brittany. European Review of Agricultural Economics 46(2): 237-266.

Sarr, A., Lybek, T. (2002): Measuring Liquidity in Financial Markets. IMF Working Paper WP/02/232.

Sherrick, B. J., Barry P. J. (2003) Farmland Markets: Historical Perspectives and Contemporary Issues. In Moss, C.B., Schmitz, A. (eds.): Government Policy and Farmland Markets: The Maintenance of Farmer Wealth, Ames: lowa State Press, 27-49.

Stein, J.C. (1995): Prices and Trading Volume in the Housing Market: A Model with DownPayment Effects. The Quarterly Journal of Economics 110(2): 379-406.

Swamy, P.A.V.B. (1970): Efficient Inference in a Random Coefficient Regression Model. Econometrica 38(2): 311-323.

Turvey, C. (2003): Hysteresis and the value of farmland: A real options approach. In: Moss, C.B., Schmitz, A. (eds.): Government policies and farmland markets: The maintenance of farmer wealth, Ames: lowa State Press 179-207.

Wheaton (1990): Vacancy, Search, and Prices in a Housing Market Matching Model. Journal of Political Economy 98(6): 1270-1292.

Wheaton, W.C., Lee, N.J. (2008): Do Housing Sales Drive Prices or the Converse? MIT Department of Economics Working Paper 08-01.

Yang, X., Ritter, M., Odening, M. (2017): Testing for regional convergence of agricultural land prices. Land Use Policy 64: 64-75.

Yang, X., Odening, M., Ritter, M. (2019): The Spatial and Temporal Diffusion of Agricultural Land Prices. Land Economics 95(1): 108-123. 


\section{Appendix}

Table A1: Annual mean of panel VAR variables for each county from 1991-2018

\begin{tabular}{|c|c|c|c|c|}
\hline County & $\begin{array}{c}\text { Turnover } \\
(\%)\end{array}$ & Return & $\begin{array}{l}\text { Number of } \\
\text { farm exits }\end{array}$ & $\begin{array}{c}\text { Share of agri. } \\
\text { sellers }(\%)\end{array}$ \\
\hline Ammerland & 0.3959 & 0.0361 & 187.59 & 41.88 \\
\hline Aurich & 0.6668 & 0.0405 & 193.13 & 32.66 \\
\hline Celle & 0.2976 & 0.0349 & 86.95 & 79.07 \\
\hline Cloppenburg & 0.3217 & 0.0537 & 164.06 & 61.16 \\
\hline Cuxhaven & 0.5206 & 0.0384 & 115.40 & 46.99 \\
\hline Diepholz & 0.4391 & 0.0452 & 162.22 & 43.17 \\
\hline Emsland & 0.3307 & 0.0488 & 178.18 & 66.20 \\
\hline Friesland & 0.2176 & 0.0325 & 112.09 & 57.67 \\
\hline Gifhorn & 0.3143 & 0.0345 & 135.89 & 81.99 \\
\hline Goslar & 0.2268 & 0.0247 & 80.48 & 41.28 \\
\hline Göttingen & 0.4167 & 0.0267 & 198.54 & 14.68 \\
\hline Grafschaft Bentheim & 0.2566 & 0.0442 & 180.97 & 71.78 \\
\hline Hameln-Pyrmont & 0.4262 & 0.0170 & 119.45 & 29.28 \\
\hline Harburg & 0.3181 & 0.0436 & 133.04 & 76.30 \\
\hline Heidekreis & 0.3693 & 0.0462 & 91.35 & 43.09 \\
\hline Helmstedt & 0.3511 & 0.0384 & 76.01 & 86.62 \\
\hline Hildesheim & 0.3208 & 0.0271 & 106.87 & 48.67 \\
\hline Holzminden & 0.4065 & 0.0187 & 136.97 & 40.36 \\
\hline Leer & 0.2907 & 0.0229 & 190.26 & 40.87 \\
\hline Lüchow-Dannenberg & 0.4223 & 0.0424 & 108.04 & 42.70 \\
\hline Lüneburg & 0.2841 & 0.0349 & 63.96 & 69.57 \\
\hline Nienburg (Weser) & 0.5431 & 0.0408 & 182.58 & 52.32 \\
\hline Northeim & 0.4162 & 0.0248 & 163.63 & 19.74 \\
\hline Oldenburg & 0.3874 & 0.0500 & 137.84 & 48.76 \\
\hline Osnabrück & 0.1965 & 0.0548 & 210.62 & 70.81 \\
\hline Osterholz & 0.3338 & 0.0160 & 144.90 & 45.81 \\
\hline Peine & 0.3083 & 0.0284 & 134.92 & 69.46 \\
\hline Region Hannover & 0.1387 & 0.0355 & 98.80 & 38.93 \\
\hline Rotenburg (Wümme) & 0.3961 & 0.0444 & 129.10 & 62.22 \\
\hline Schaumburg & 0.4606 & 0.0209 & 182.88 & 68.63 \\
\hline Stade & 0.3616 & 0.0427 & 145.34 & 65.53 \\
\hline Uelzen & 0.1510 & 0.0395 & 73.73 & 69.20 \\
\hline Vechta & 0.2903 & 0.0470 & 178.39 & 68.60 \\
\hline Verden & 0.3986 & 0.0414 & 150.96 & 40.19 \\
\hline Wittmund & 0.2024 & 0.0460 & 180.37 & 38.00 \\
\hline Wolfenbüttel & 0.2129 & 0.0268 & 70.67 & 72.68 \\
\hline
\end{tabular}

